تعيين رقم و تاريخ كشت ايدهال گندم ديم (Triticom aestivum L.) منطقه گنبد كاووس با استفاده از تكنيك GGE باىيلات

كلدى محمد بهلكه'، عباس بيابانى '، حسين صبورى ץ* و حسينعلى فلاحى"

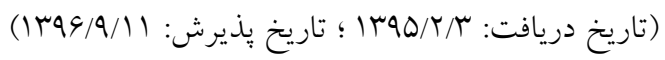

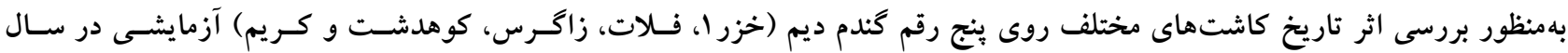

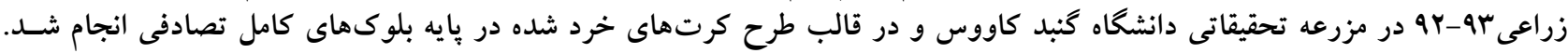

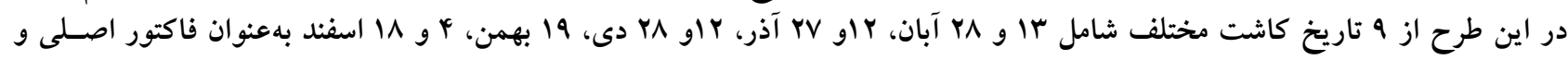

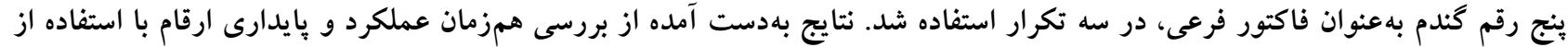

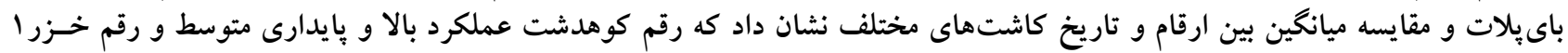

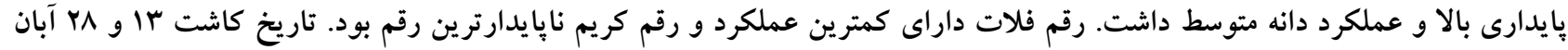

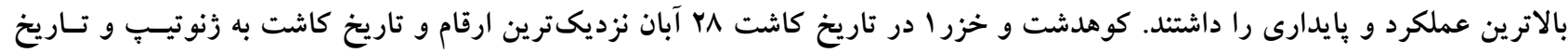

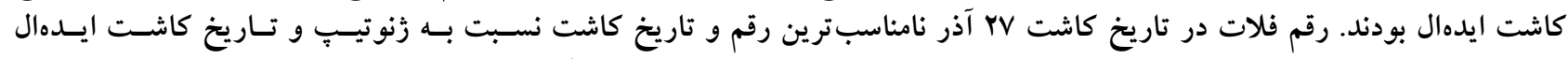

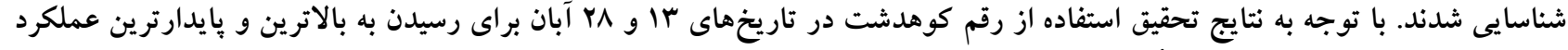

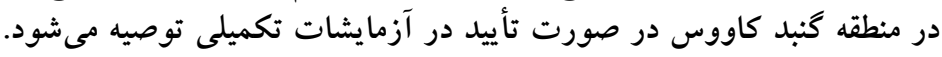

وازٔهاى كليدى: پايدارى، رقم كوهدشت، زُنوتيب ايدهال، عملكرد و اجزاى عملكرد

ا. دانشجوى كارشناسى ارشد، گروه توليدات گياهى، دانشكده كشاورزى و منابع طبيعى، دانشگاه گنبد كاووس r. دانشياران گروه توليدات گياهى، دانشكده كشاورزى و منابع طبيعى، دانشگاه گنبد كاووس r. استاديار بخش تحقيقات زراعى و باغى، مركز تحقيقات و آموزش كشاورزى و منابع طبيعى مازنـدران، سـازمان تحقيقـات آمـوزش و تـرويج كشاورزى، سارى، ايران * hos.sabouri@gmail.com مسئول مكاتبات، يست الكترونيكى 
كاشت تا سبز شدن و تعداد روز از سبز شدن تـا سـاقدهـى در

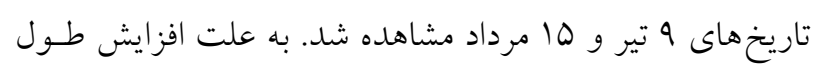

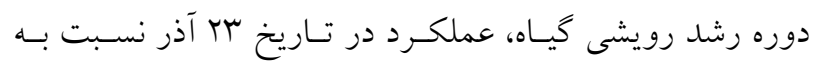

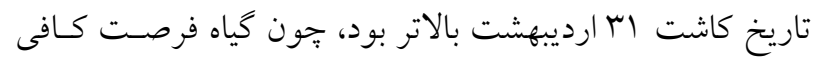

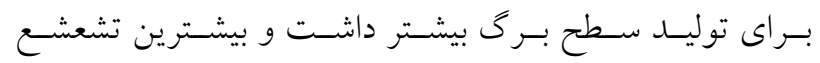

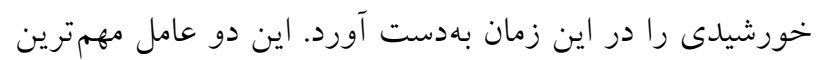

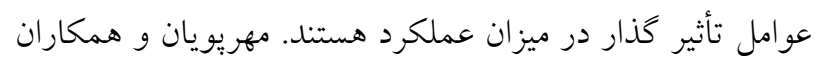

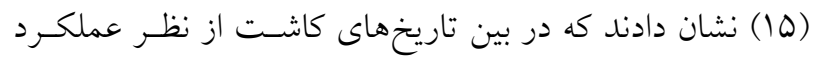

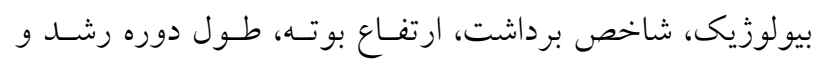

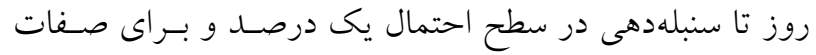

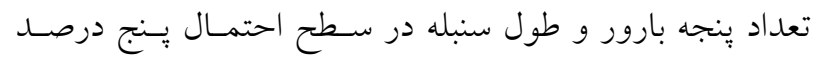

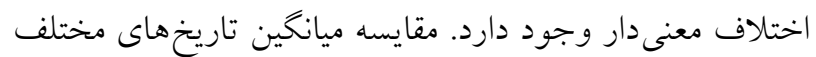

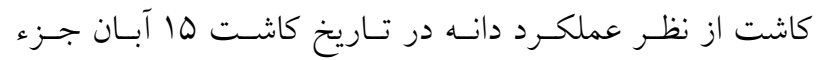
بهترين تاريخهاى كاشت در منطقه گزارش شــــ عملكـرد دانـه بالاتر در اين تاريخ كاشت ناشى از طول دوره رشد بيشتر، طول

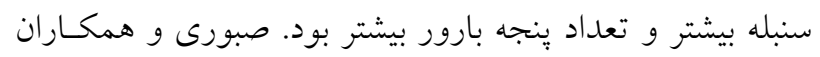

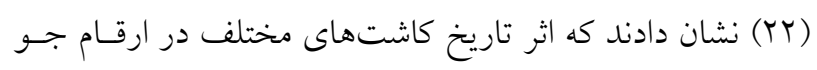
در بيشتر صفات زراعسى بـهـهـز ارتفـاع بوتـه، معنسى دار اسـتـ.

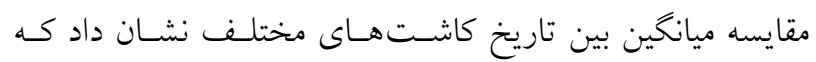

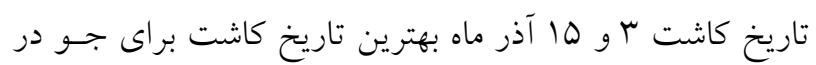
منطقه كنبدكاووس است.

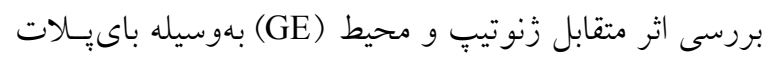

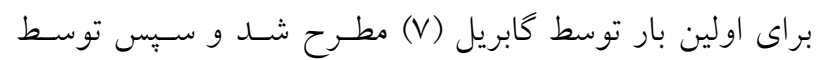
كميتون (Y) (I و زوبل و همكاران (YN) توسعه يافت، اما كاربرد

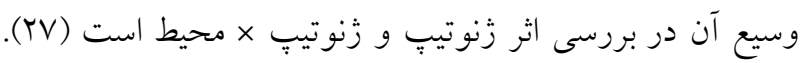

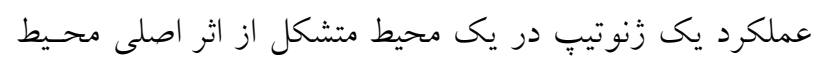

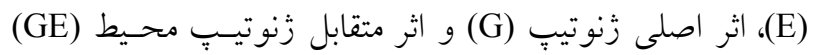
است. علىرغم اينكه اثر محيط ميزان زيادى از درصد تغييرات كل عملكرد را توجيه مى كند و اثرهـاى زنوتيسِ و زنوتيسِ محيط كوجکكتر هستند، اما اين دو اثر در آزمايشهاى ارزيـابى زنوتيبها دخيل بوده و در زمان كزينش زنوتيبهاى برتر، اثر

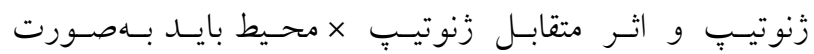

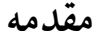

تاريخ كاشت عاملى است كه اغلب خصوصيات فيزيولوزيـك و

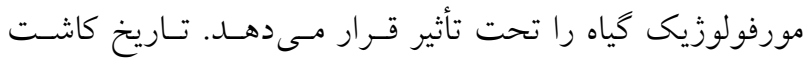
مطلوب باعث مىشود كه شـر ايط محيطى مناسـبى بــر اى سـبز

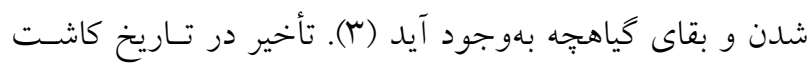

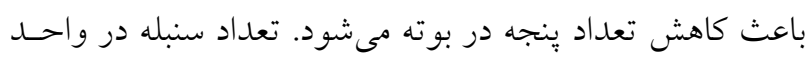

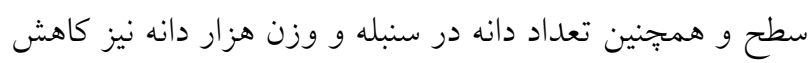

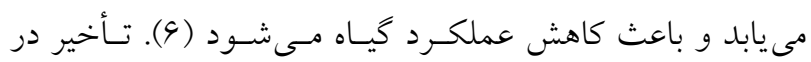

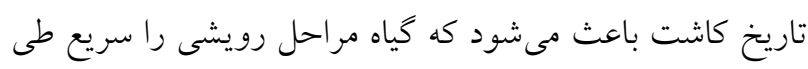

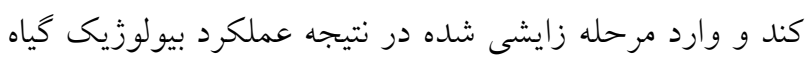

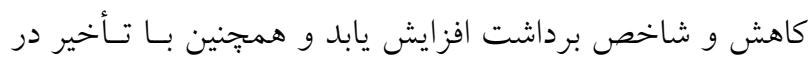

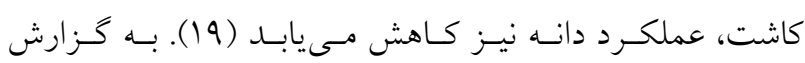

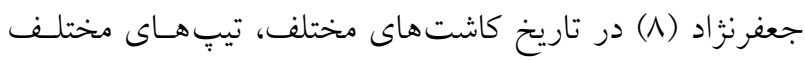
رشدى گندم واكنشهاى متفاوتى دارند. بهطورى كه با تأخير در

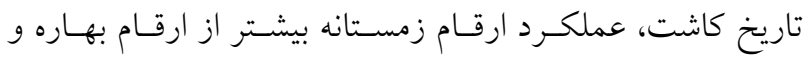
بينابين كاهش يافت كه علت اصلى آن كـاهش تعـداد سـنبله در

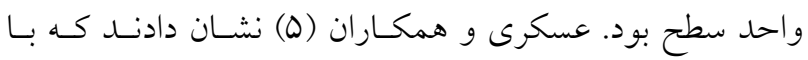

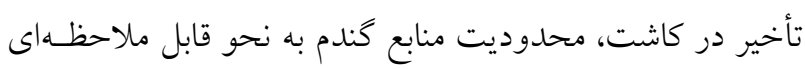

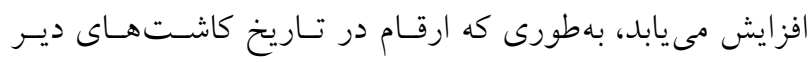

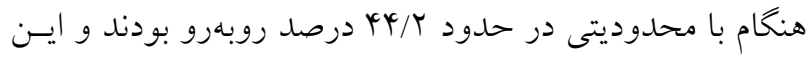

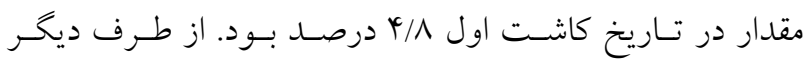

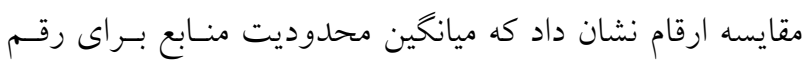

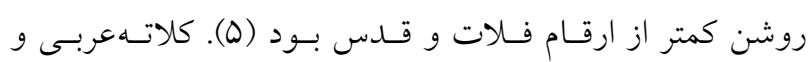

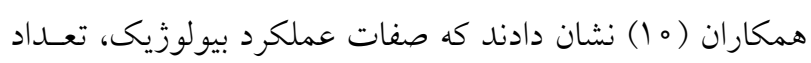
سنبله در واحد سطح، روز تا سنبلهدهى، روز تا رسيدن و مقدار

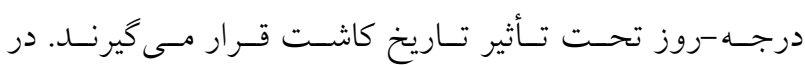

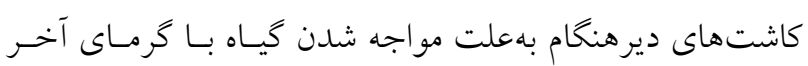

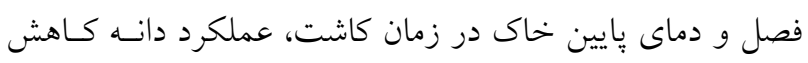

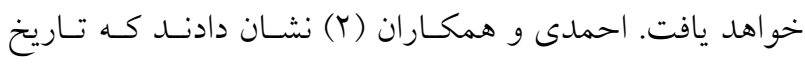

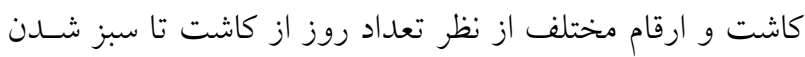
و تعداد روز از سبز شدن تا ساقهدهى اختلاف معنى دار دارند. از

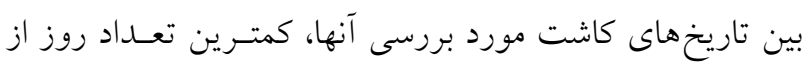


جدول ا. خلاصهاى از برخى بِارامترهاى جوى منطقه كنبد كاووس در طى دوره آزمايش

\begin{tabular}{|c|c|c|c|c|c|c|c|c|}
\hline \multirow{2}{*}{ تبخيرماهانه } & \multirow{2}{*}{ روزهاى } & \multirow{2}{*}{$\begin{array}{l}\text { بارندكى } \\
\text { (mm) }\end{array}$} & \multicolumn{2}{|c|}{ رطوبت (\%) } & \multicolumn{2}{|c|}{ دما ( ) } & \multirow{2}{*}{ ماه } & \multirow{2}{*}{ سال } \\
\hline & & & Max & Min & Max & Min & & \\
\hline$\Delta \circ / \Delta$ & 。 & $10 / 0$ & 90 & 14 & $r \circ / 9$ & $0 / 9$ & آبان & Irar \\
\hline YN/A & 1 & $V \circ / \Lambda$ & $9 V$ & 19 & $\Gamma^{\top} / \Lambda$ & $-0 / r$ & آذر & Irar \\
\hline$r \mu / V$ & 9 & $9 / 0$ & 100 & TV & $r Y / r$ & $-r / 9$ & دى & Irar \\
\hline$r \Delta / q$ & 10 & $r Q / V$ & 100 & r & $T V / T$ & -9 & بهمن & Irar \\
\hline r & 1 & $\forall \varphi / \Lambda$ & 100 & ه & $r Q / \varphi$ & $-0 / 9$ & اسفند & Irar \\
\hline $\mathrm{V} / \mathrm{r}$ & 1 & $\Delta \Delta /{ }^{\uparrow}$ & 100 & TG & $r T / 4$ & $-0 / r$ & فروردين & Irar \\
\hline $\mid F V / 1$ & $\circ$ & rN/Y & 91 & 14 & $r q / 9$ & $10 / \pi$ & ارديبهشت & lrar \\
\hline $190 / 9$ & 。 & $K Y / \varphi$ & 91 & 11 & $\hat{k Y / 9}$ & 11 & خرداد & irar \\
\hline
\end{tabular}

اختصاص داد. در مقاله حاضـر محققسين اثـر متقابـل ارقـام و

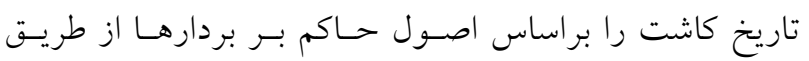
روش باى يلات تجزيه نمودند. به عبارت بهتـر هـدف از ايسن

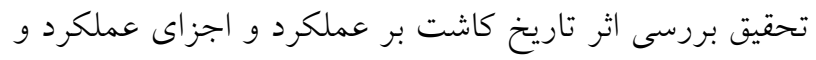

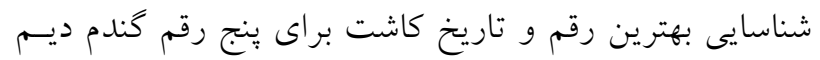

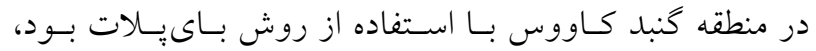

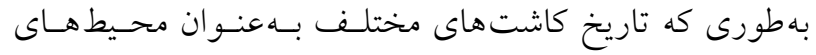
مختلف درنظر كرفته شدند.

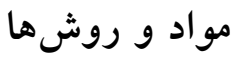

اين آزمايش در سال زراعى سو-Y دور مزرعه تحقيقاتى دانشگاه كَنبد كاووس و در قالب طـرح كـرتهـاى خـرد شـــه در بايـهـ بلوكهاى كامل تصادفى انجام شد. در اين بررسى از يــنج رقـم

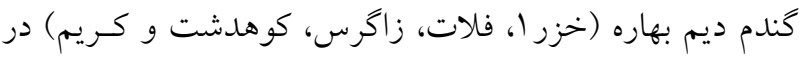

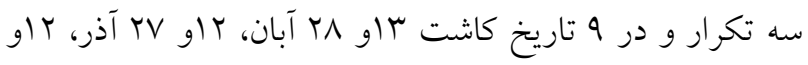

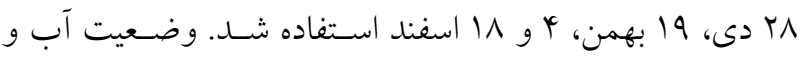
هوايى منطقه در تاريخهاى مذكور در جدول آمآمده است. ابعاد

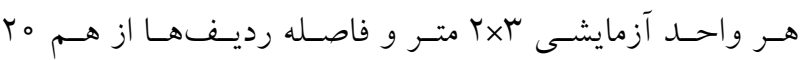

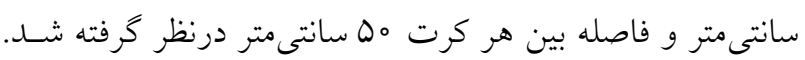

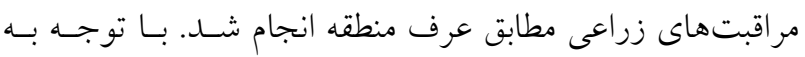

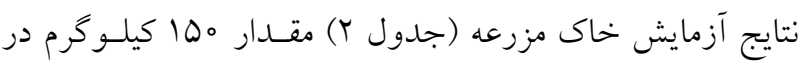

تو أم مد نظر قرار كيرند (Yo). از كاربردهاى مهـم بـاىيـلات

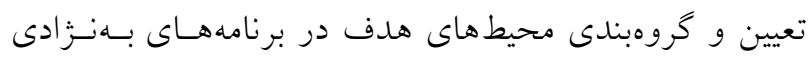
محصولات مختلف است. با استفاده از باى يـلات محسيطهـاى

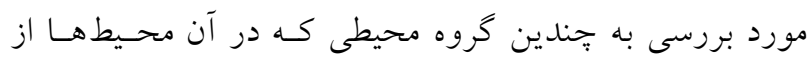

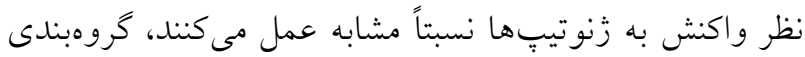
مىشوند. گروهبندى محيطها براى محصولات زراعى مختلف

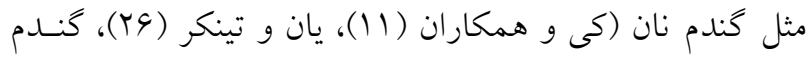

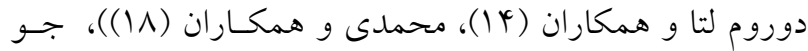

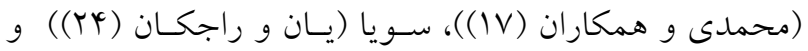

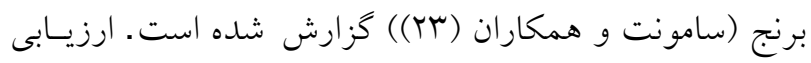
لاين هاى بيشرفته اصلاحى در محيطهاى مختلف اين امكان را فراهم مى كند كه محيطها از نظر باسخ هاى مشابه به كروههاى

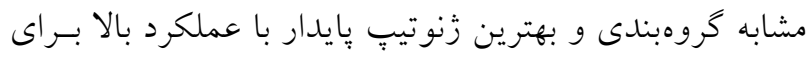

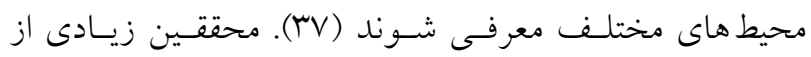

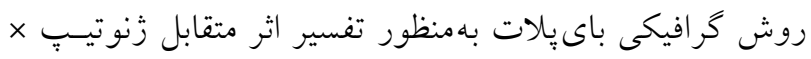

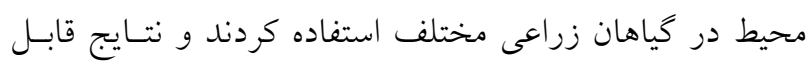

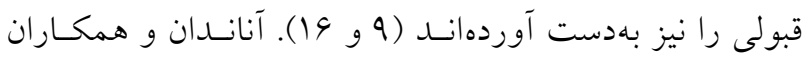

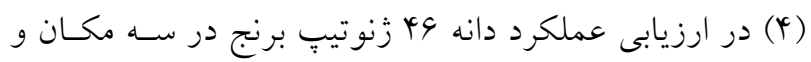

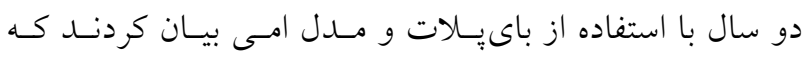

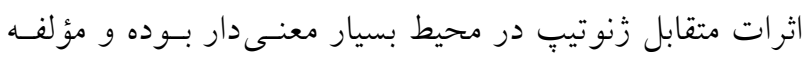

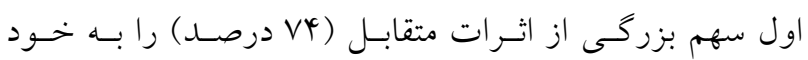


جدول r. نتايج تجزيه فيزيكى و شيميايى خاك

\begin{tabular}{|c|c|c|c|c|c|c|c|}
\hline بافت خاى & نيتروزن & $\begin{array}{l}\text { بتاسيم } \\
\text { (ppm) }\end{array}$ & $\begin{array}{c}\text { فسفر) } \\
\text { (ppm) }\end{array}$ & ماده آلى & $\begin{array}{c}\mathrm{EC} \\
(\mathrm{dS} / \mathrm{m})\end{array}$ & $\mathrm{pH}$ & خاى \\
\hline سيلتى رسى لوم & $0 / 14$ & KuV & $10 / 9$ & $1 / 0$ & I/V & $V / 9$ & \\
\hline
\end{tabular}

روز تا ساقهدهى اختلاف معنى دارى در بـين ارقـام وجـود نــدارد

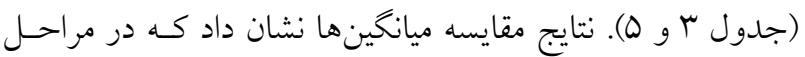

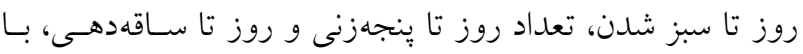

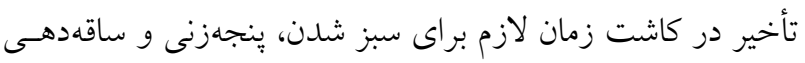

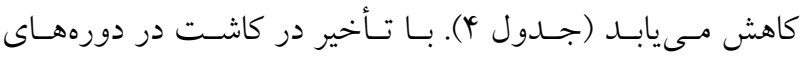

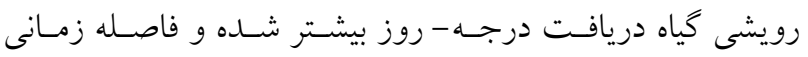

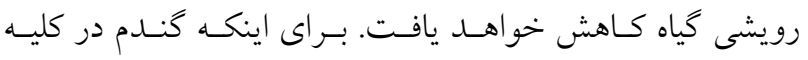

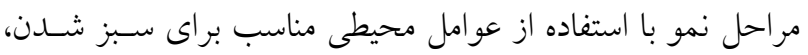

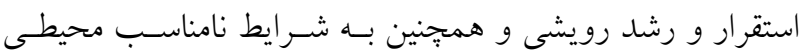

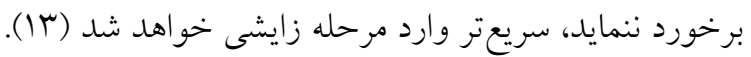

سنبلهدهى، رسيدگى فيزيولوزيكى و دوره بر شدن دانه

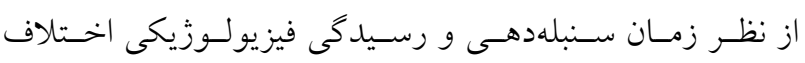

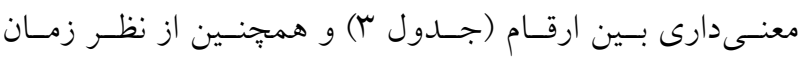

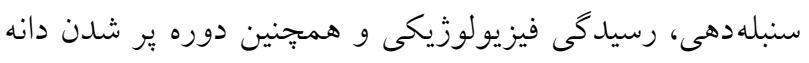

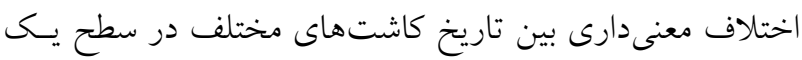

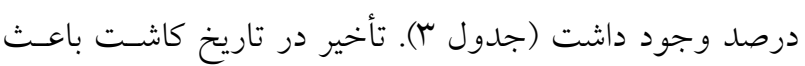
مىشود زمان كمترى صرف سنبلهدهى و رسيدگى فيزيولوزيكى

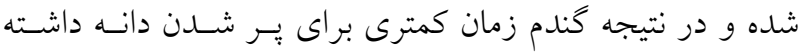
باشد و كَاه با تنشهاى آخر فصل مواجه مى شيود كه ايسن عمـل

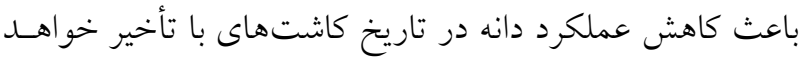

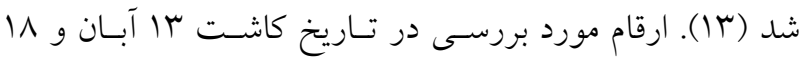
اسفند بهترتيب بيشترين و كمترين زمان را براى يـر شــدن دانسه

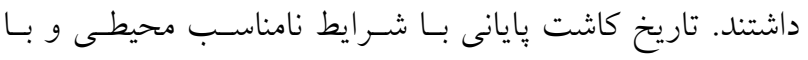

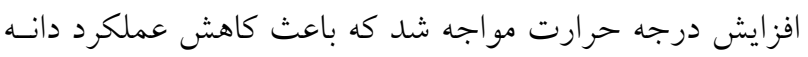

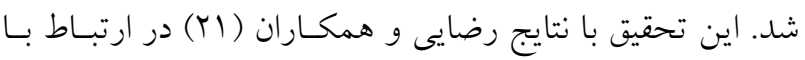
تاريخ كاشت مطابقت داشت.
هكتار كود نيتروزن در سه مرحله، قبل از كشت، در پنجهدهى و سنبلهدهى به كرتها داده شد. صفات فنولـوزيكى مانــــ تعـداد

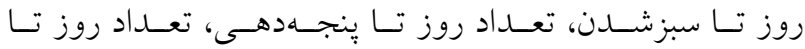

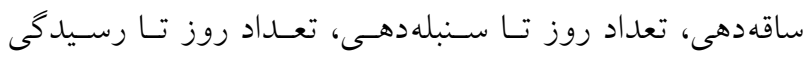

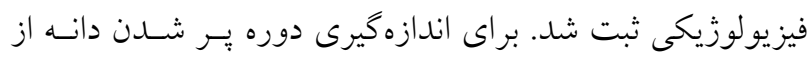
اختلاف بين صفات تعداد روز تا رسيدكى فيزيولوزيكى و تعداد

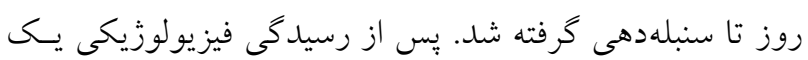

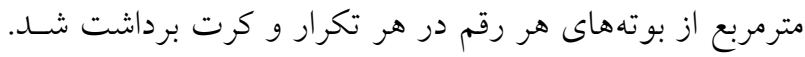

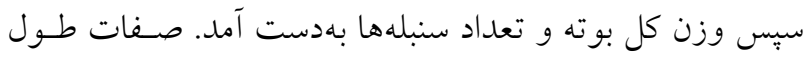

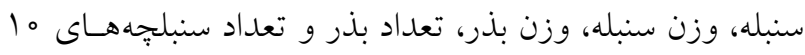
سنبله تصادفى از سنبلههاى كرت بدون درنظر كرفتن بوتـهــاى كنارى ثبت شد. تجزيه واريانس و نتايج مقايسههاى ميانخين بـهـ روش LSD با استفاده از نرم|فزار SAS9.1 انجام شد. بـهـمنظور

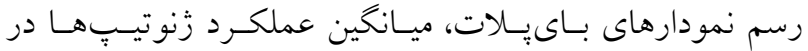
محيطهاى مختلف بهصورت يكى ماتريس دو طرفه تنظيم و بـهـ نرمافزار GGE Biplot معرفى شد.

\section{نتايج و بحث}

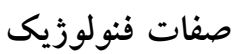

نظر به عـدم معنسى دارى تكــرار و كمتــــــودن سـودمندى طـرح

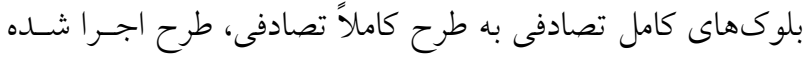

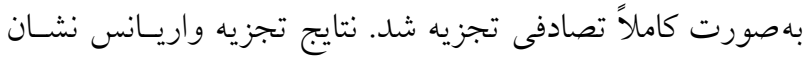

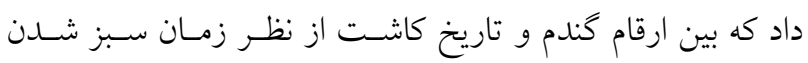

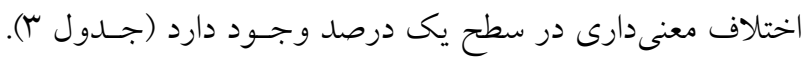

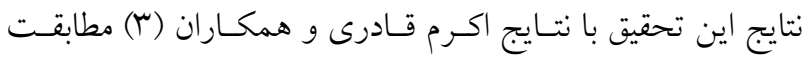

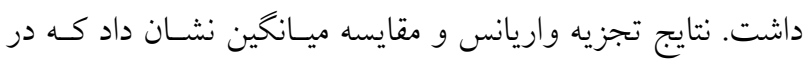

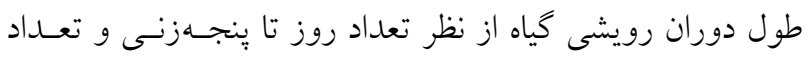




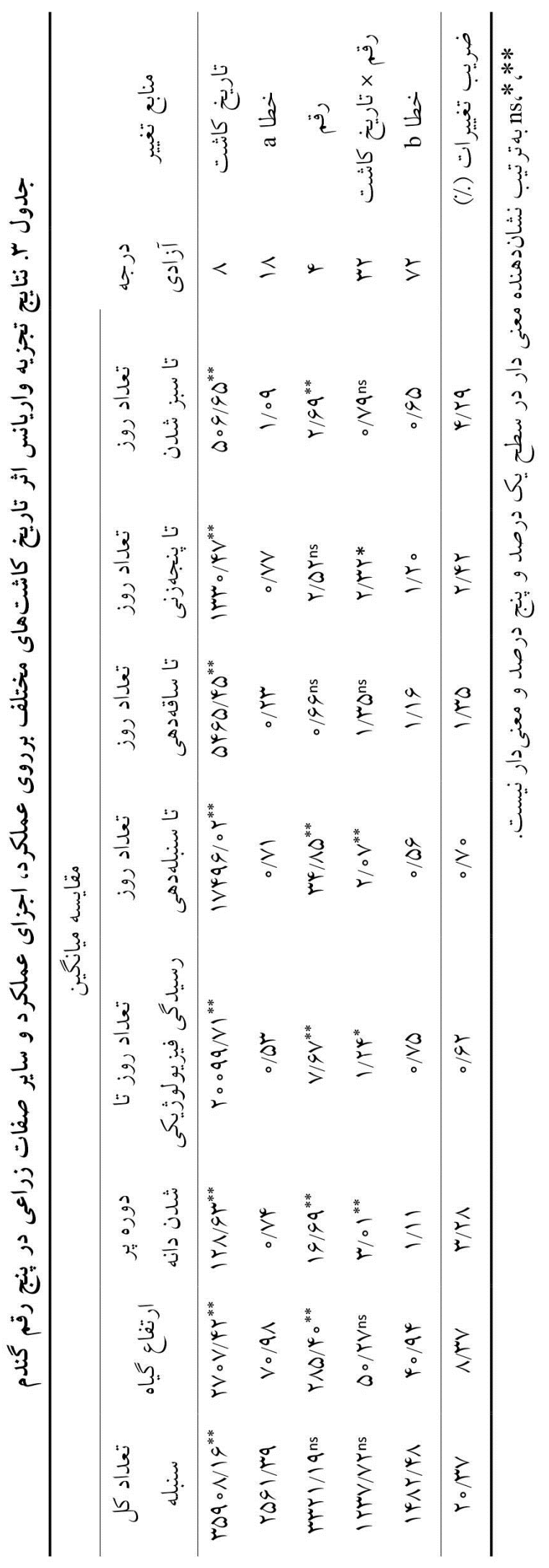




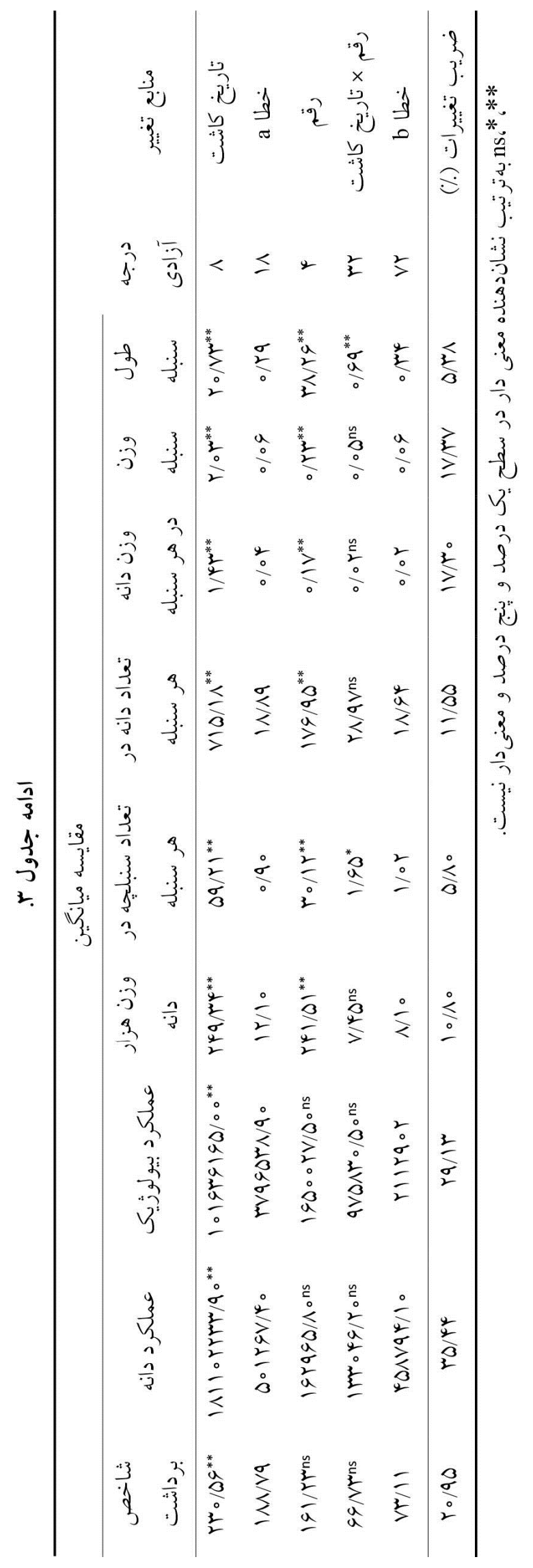




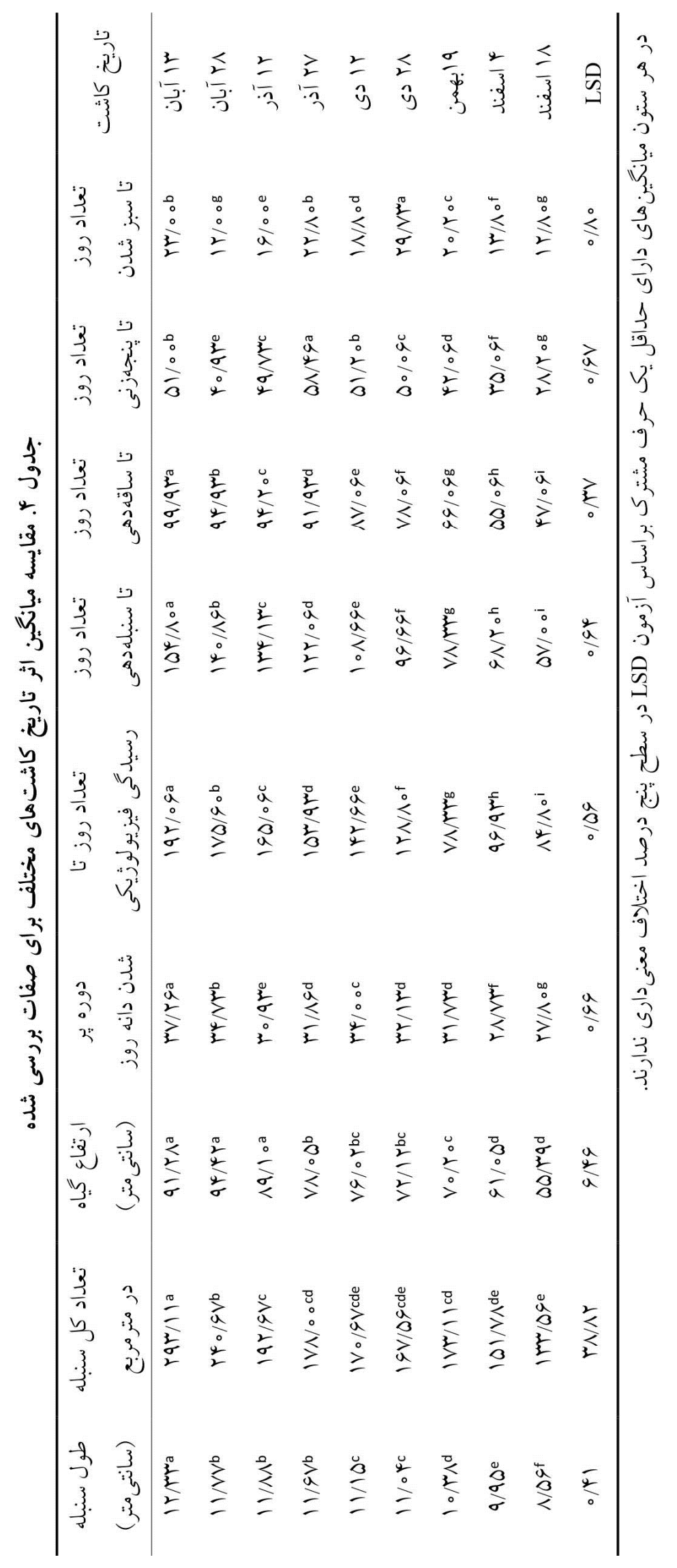




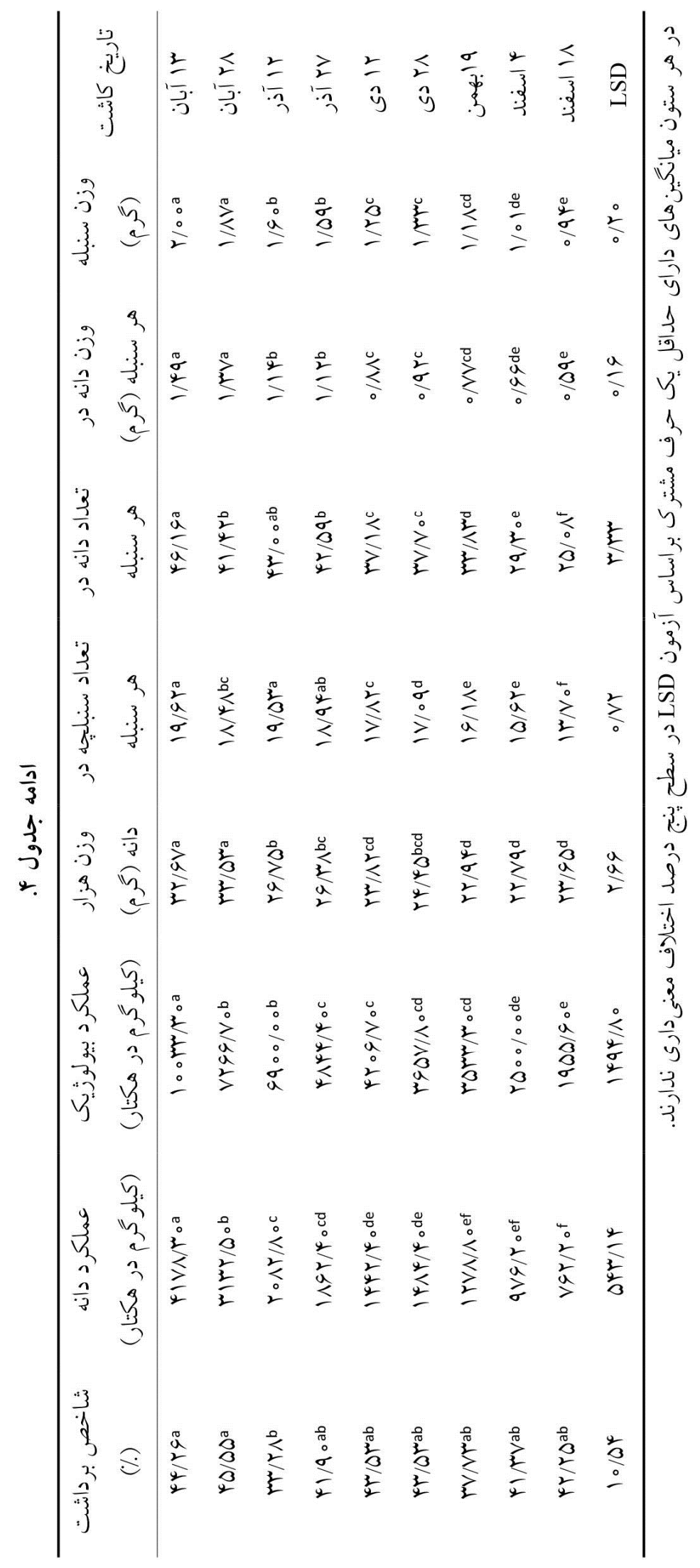


كاهش وزن سنبله در كياه مىشود. بيشترين وزن سنبله در تاريخ

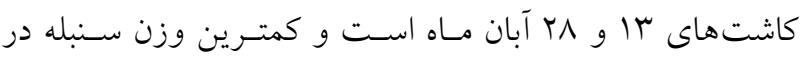

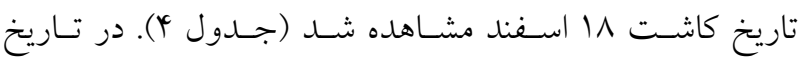

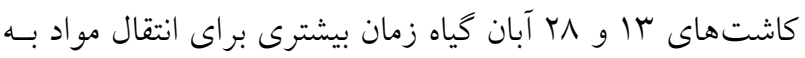

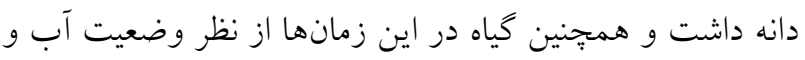
هوايى در زمان بهترى قرار داشت كه اين دليلى بر افـزيش وزن سنبلهها است. در بين ارقام كشت شده رقم فلات كمتـرين وزن سنبله را داشت و ارقام ديخر با هم اخـتلاف معنسى دار نداشـتند (جدول ه). وزن دانه در سنبله، تعـداد دانـه در سـبنه و تعـداد سنبلجه در سنبله از صفاتى هستند كه در وزن هـز ار دار دانـه تـأثير دارند. به گزارش احمدى و همكارن (1) تعداد سـنبلجه در هـر

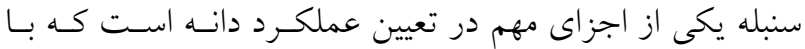
تأخير در كاشت، تعداد سنبلحه در سنبله كـاهش مسيابـــ ايسن

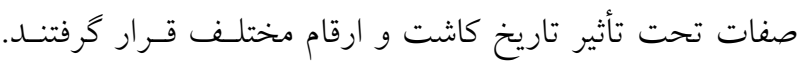
تأخير در تاريخ كاشت باعـث كـاهش وزن دانـه، تعـداد دانسه و

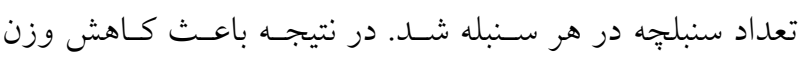

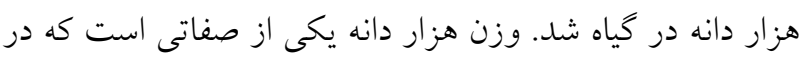

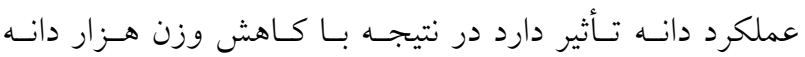

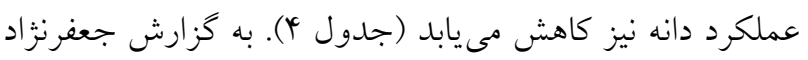

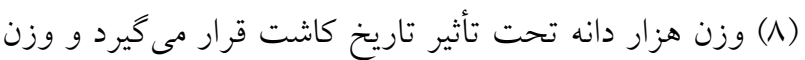

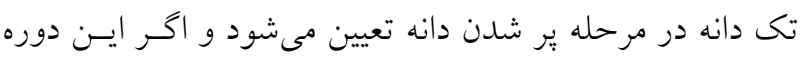

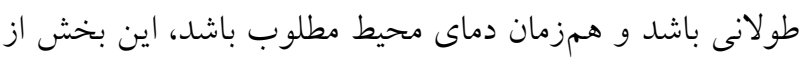
عملكرد افزايش مىيابد. بين ارقام كُندم ديم اختلاف معنىدارى در سطح يك درصد در وزن هزار دانه بود (جدول بمان.

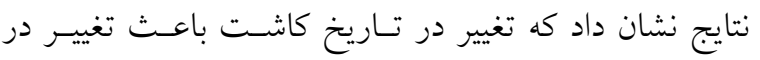

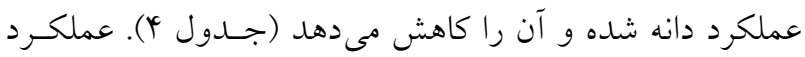

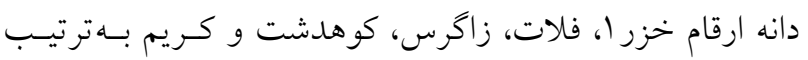
(19V0/\%。

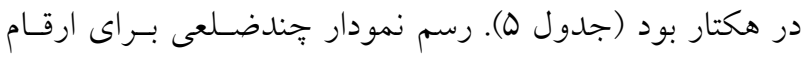

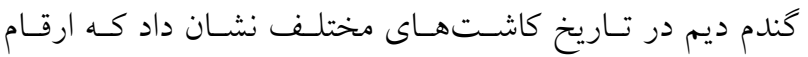
كوهدشت، كريم، زاكرس و فلات كه بيشترين فاصله را از مركز

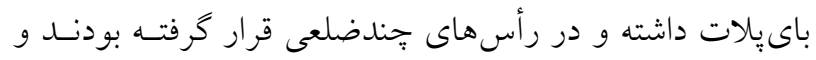

ارتفاع گیاه نتايج تجزيه واريانس نشان داد كـه در بـين تـاريخ كاشـتهــاى

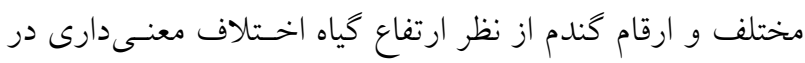

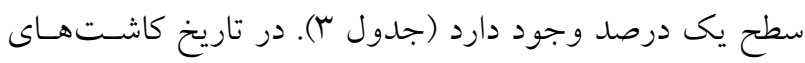

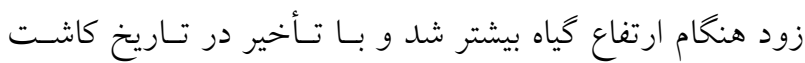

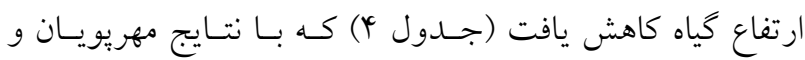
همكاران (10) مطابقت داشت. علـت كـاهش ارتفـاع در تـاريخ

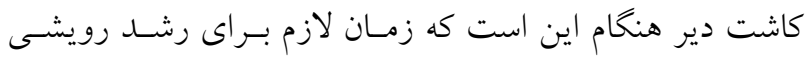
كَاه كاهش يافته و كَاه زودتر وارد فاز زايشى مىشود (rا). در

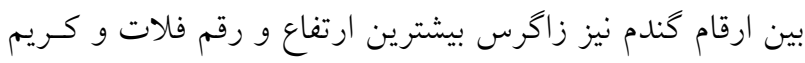

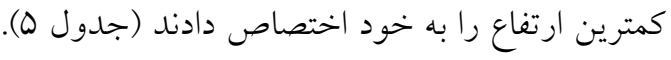

\section{عملكرد و اجزاى عملكرد}

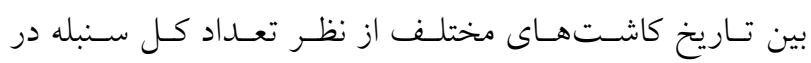
مترمربع اختلاف معنى دارى وجود داشت، امـا بــين ارقـام كَنـدم

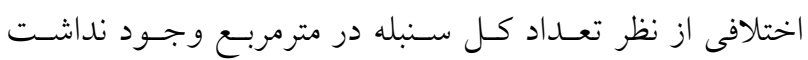

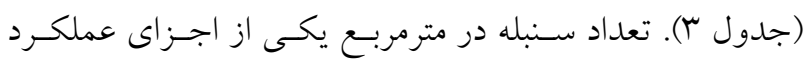

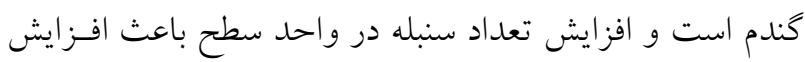

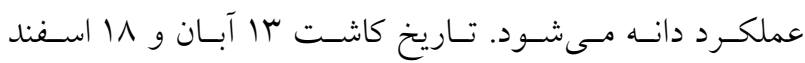

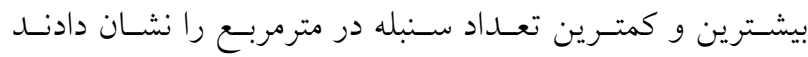

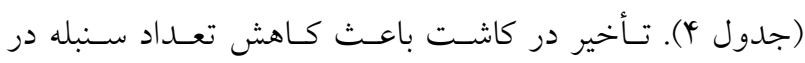
مترمربع مىشود كه اين يكى از دلايل كاهش عملكرد در تـاريخ

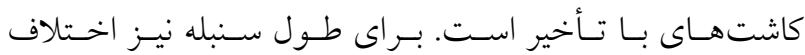

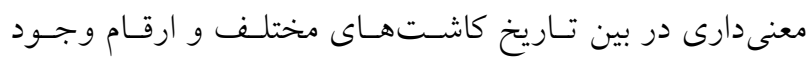

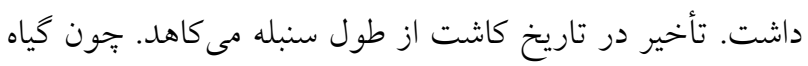

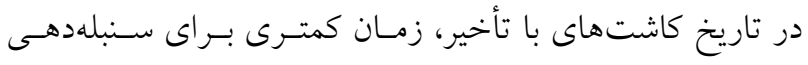

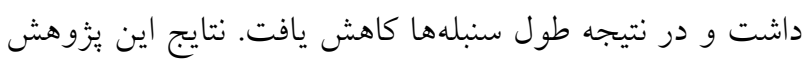

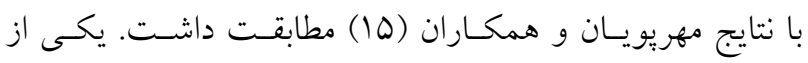
دلايل كاهش عملكرد دانه كاهش طول سنبله است. يكسى ديخـر

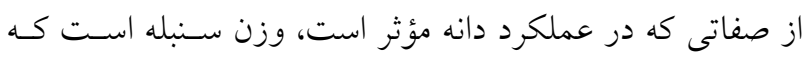

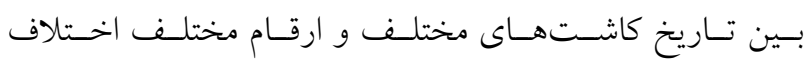

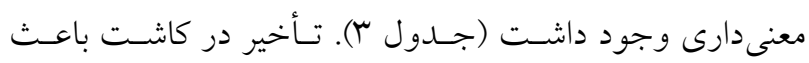




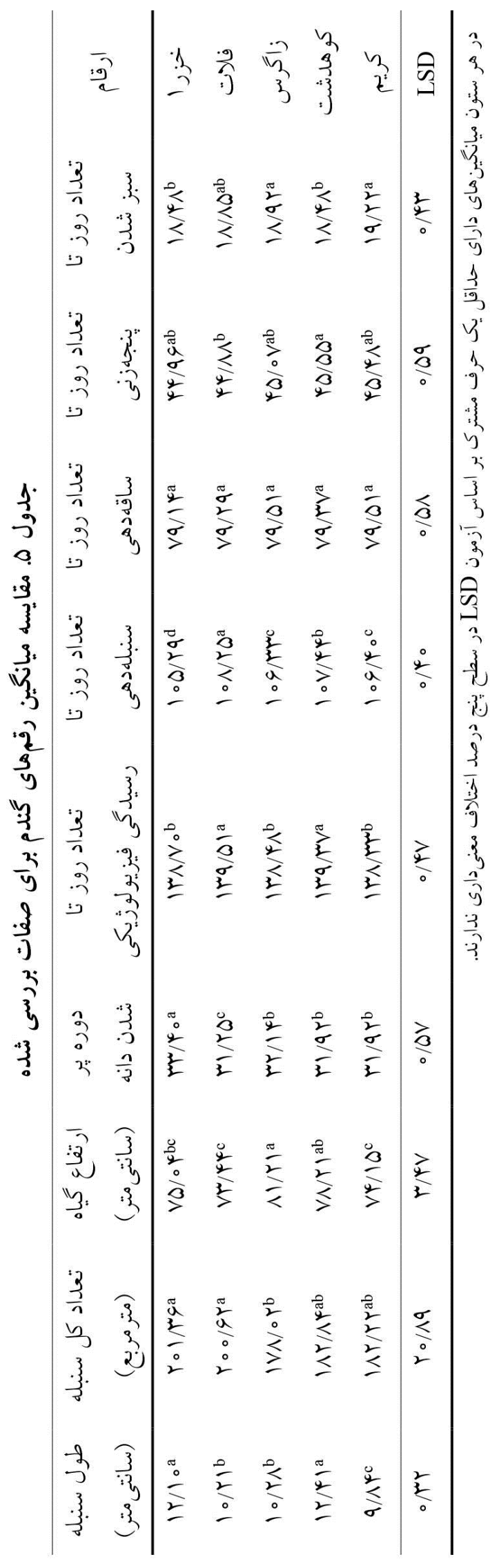




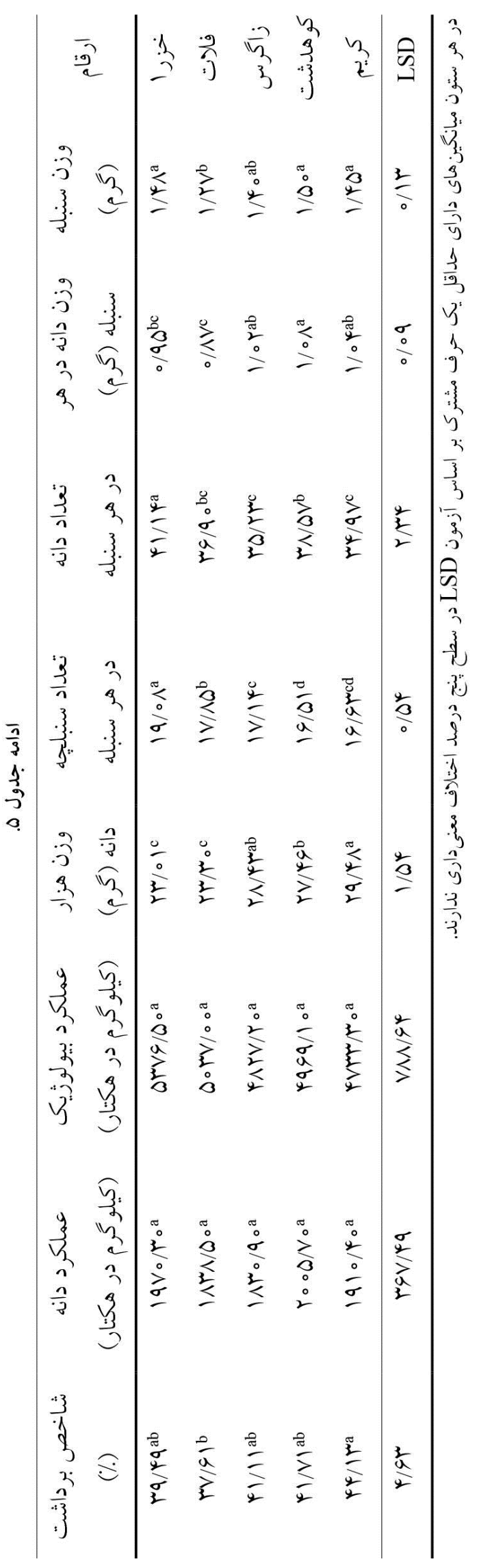




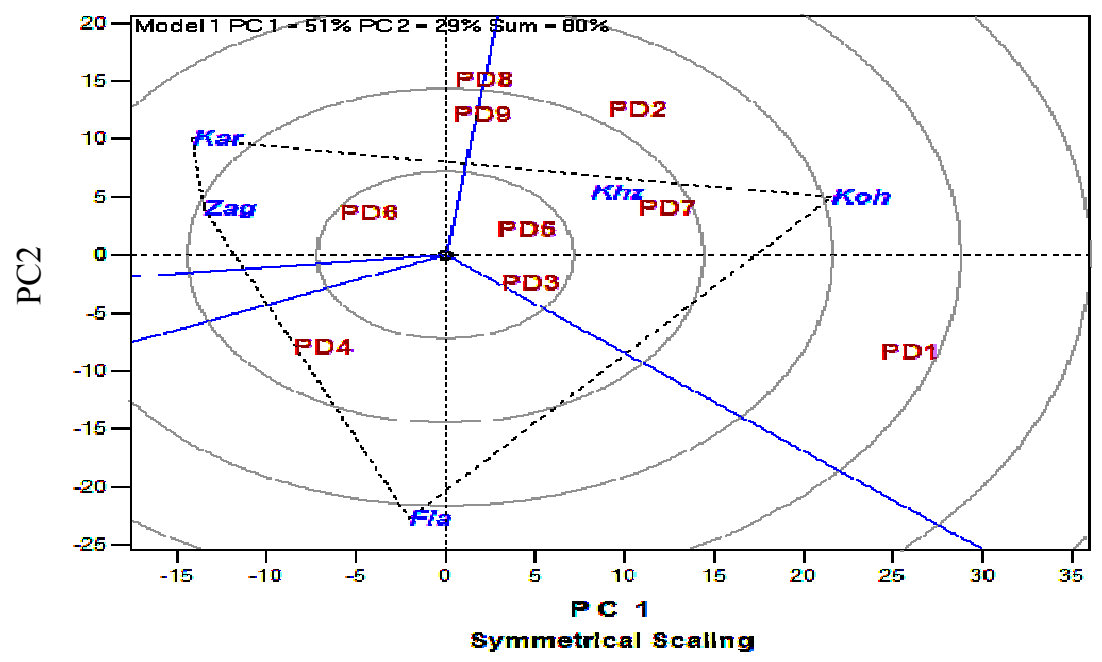

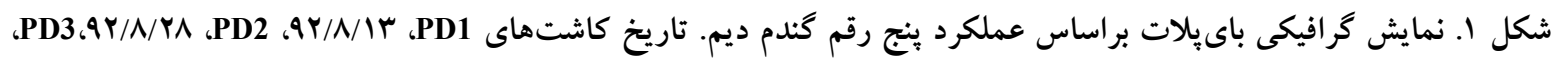
PST PD4،9Y/9/1Y

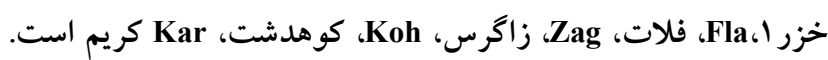

كُندم شده و در نتيجه باعث كاهش عملكـــد بيولـوزيكى گنـدم

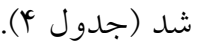

شاخص برداشت

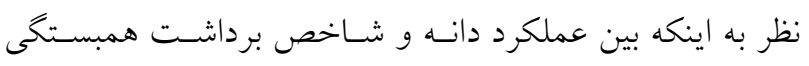

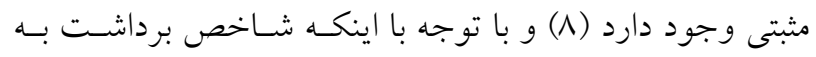

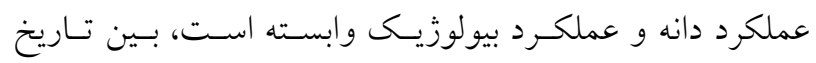

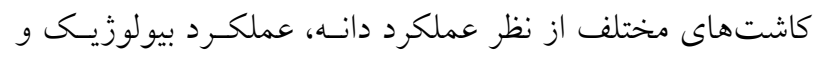
شاخص برداشت اختلاف معنى دارى در سطح يك درصد ديـده

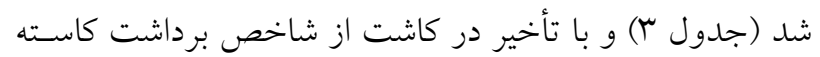

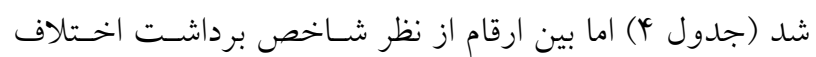

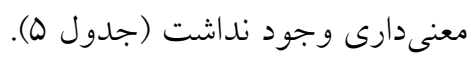

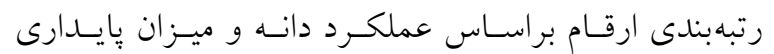
عملكرد در 9 تاريخ كاشت در شكل r نشان داده شده است. در فئر شكل محورى كه با دايره و فلش مشخصص شــده، نشـاندهنـده

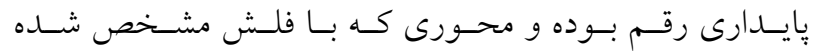

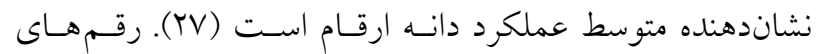

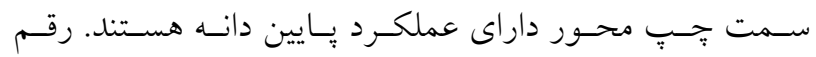

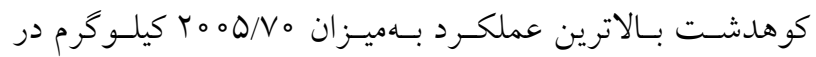

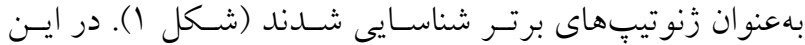

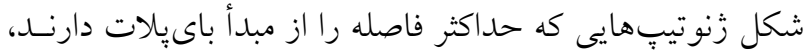

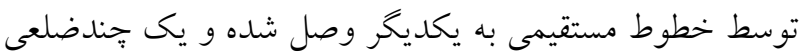

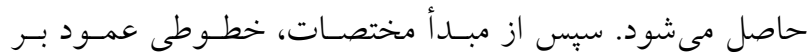

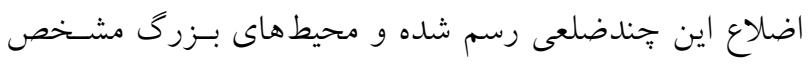

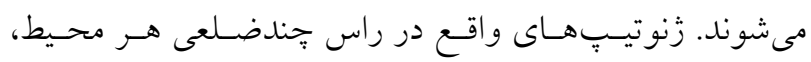

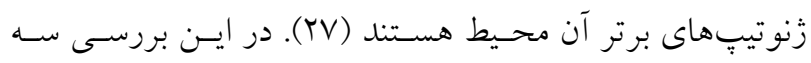

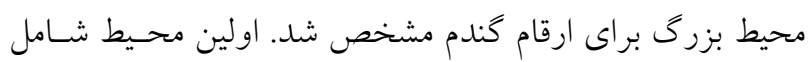

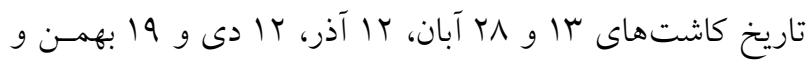

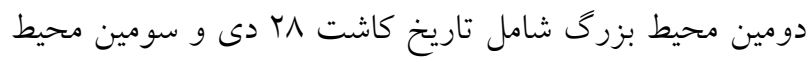

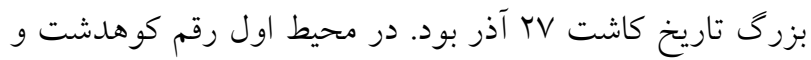
در محيط دوم ارقام زاگرس و كريم و در محيط سوم رقم فلات

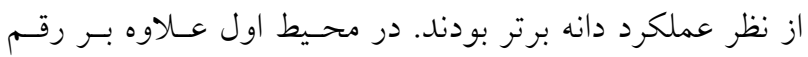

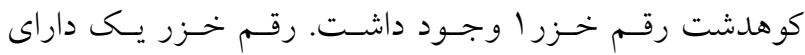

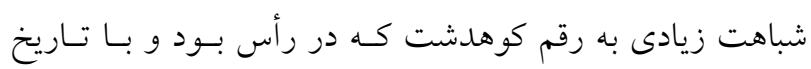
كاشتهاى مربوطه در اين محيط ساز كارى داشت.

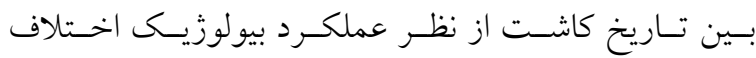
معنى دارى در سطح يك درصد وجود داشت (جدول r) تـأخير در تاريخ كاشت باعث كاهش تعداد روز در رشد فيزيولـوزيكى يحس 


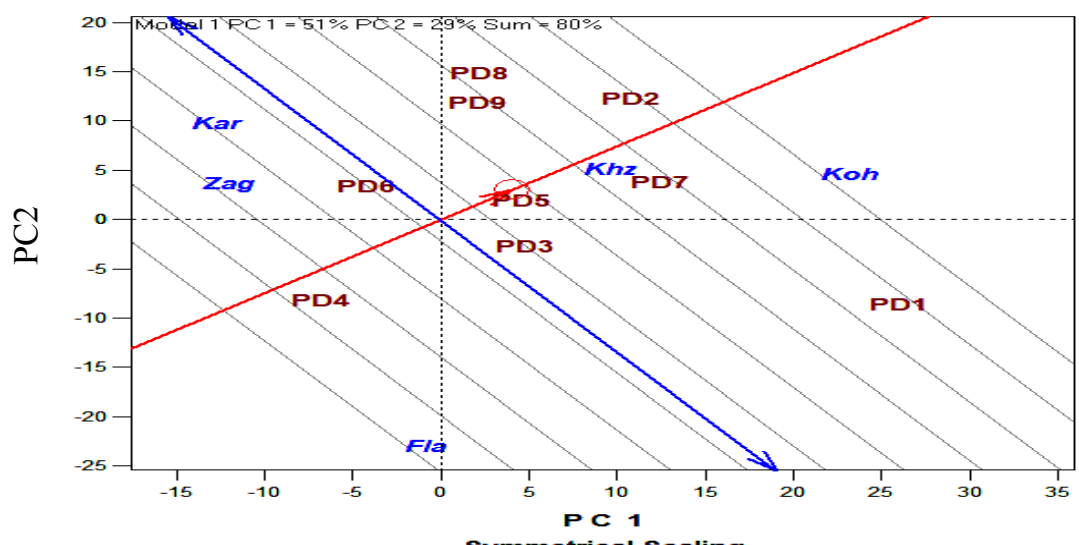

شكل Y. ارزيابى بنج رقم آزمايش شده در 9 تاريخ كاشت بهطور همزمان براساس عملكرد دانه و پايدارى عملكرد. تاريخ كاشتهاى PD1

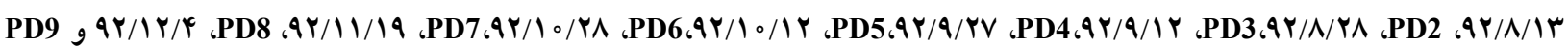


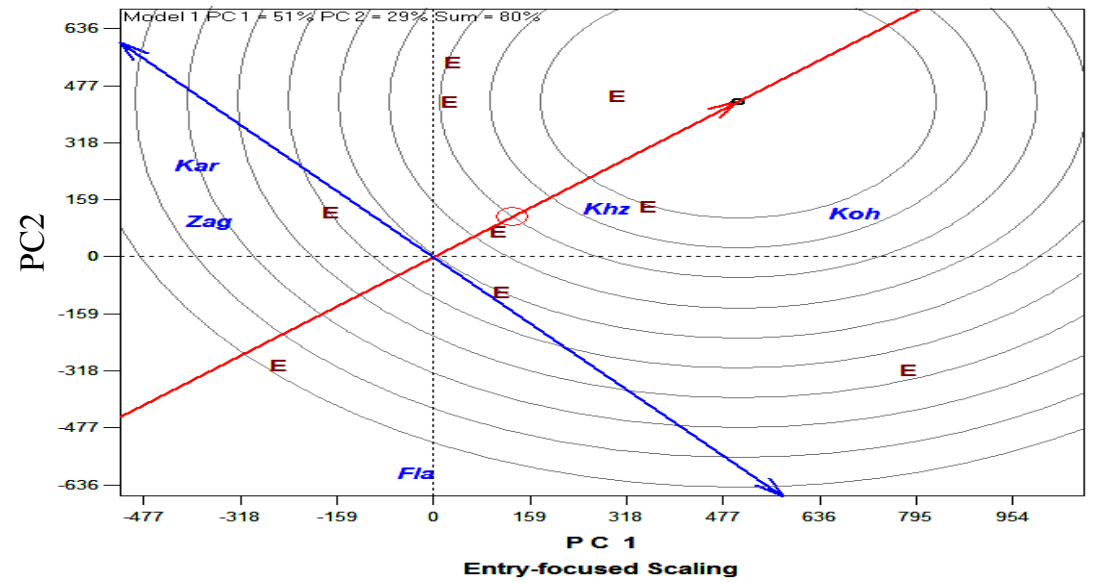

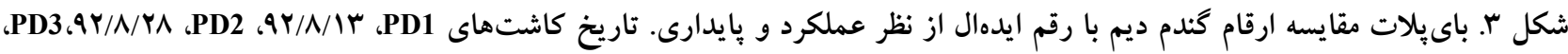
P خزر 1، Fla، فلات، Zag، زاگرس، Koh، كوهدشت، Kar و كريم است.

داشت (جدول ץ و شكل r).

شـكل r براســاس رقــم ايـــهال فرضسى (يايسـدارترين و يرمحصول ترين رقم در مركـز دوايــر متحـــالمركز) رسـم شـــه

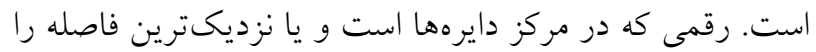

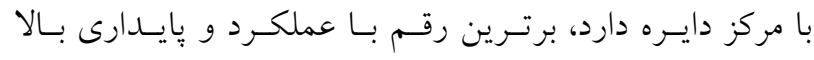

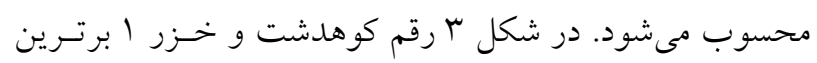

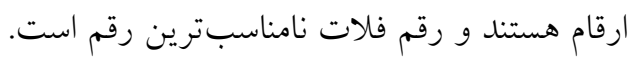
شكل ץ براساس تاريخ كاشت ايدهال فرضى (داراى عملكرد هكتار را داشته است و پِيدارى متوسطى دارد و بعد از آن رقـم

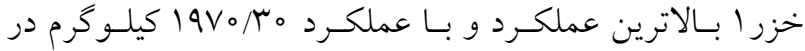
هكتار بيشترين بايدارى را داشت (جــول ه و شـكل Y). رقـم فـلات كمتـــين عملكـــد را داشـت و ارقــام كـريم و فـلات

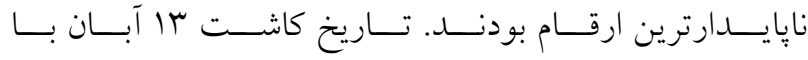

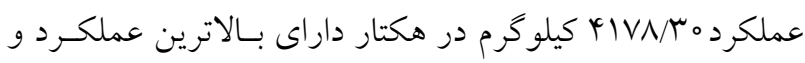

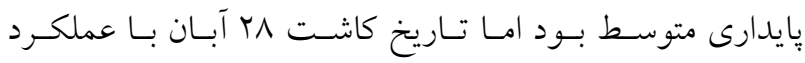

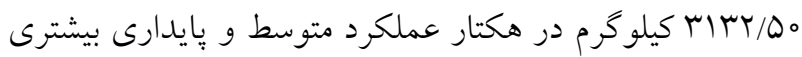




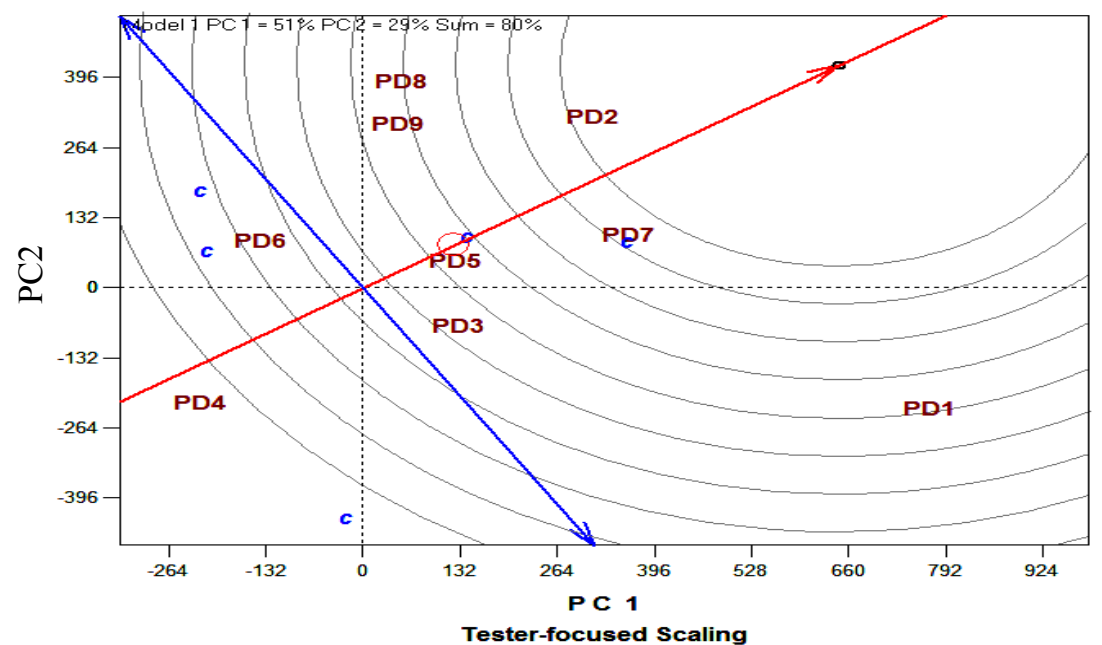

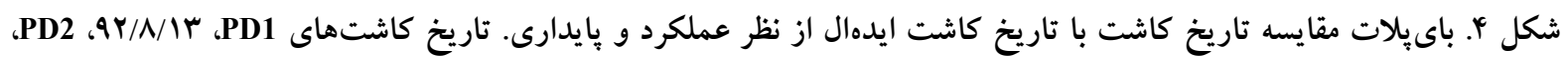

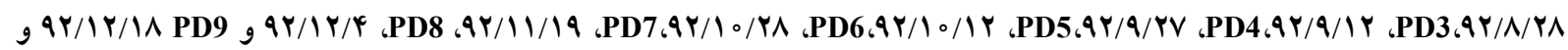
ارقام Khz، خزر 1، Fla، فلات، Zag، زاكرس، Koh، كوهدشت، Kar و كريم است.

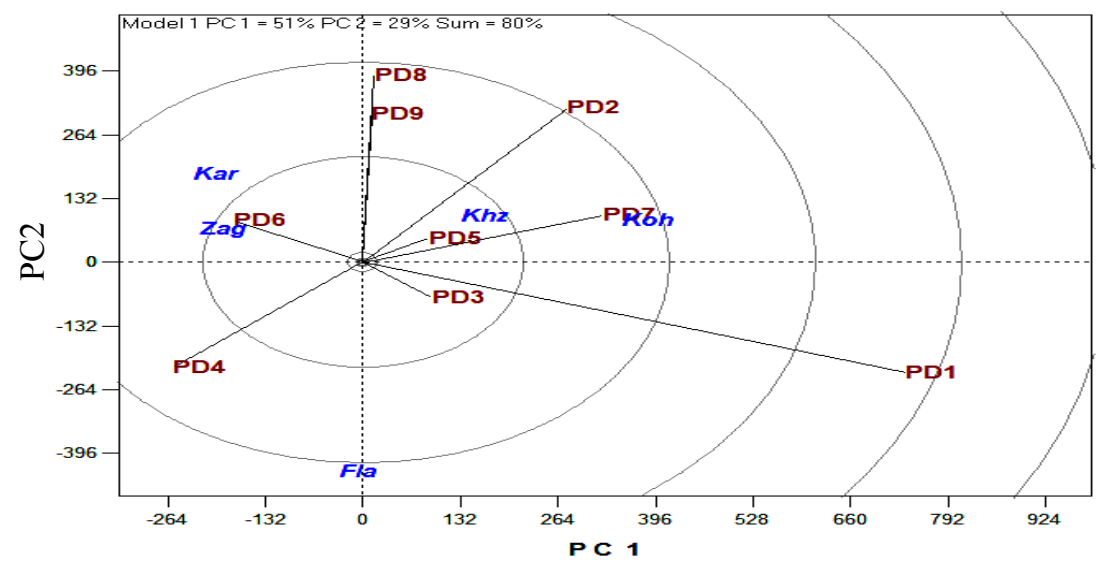

Tester-focused Scaling

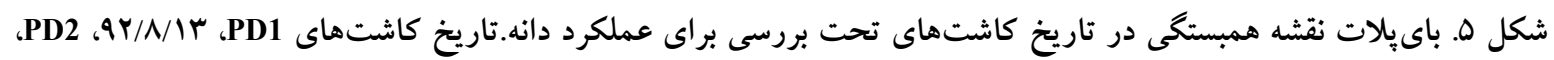

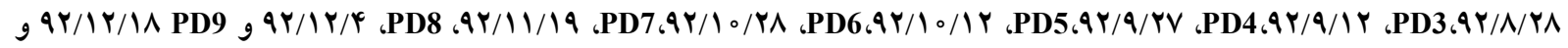

$$
\text { ارقام Khz ، خزر 1، Fla، فلات، Zag، زاگُس، Koh، كوهدشت، Kar و كريم است. }
$$

همبستخى بين بردارها مثبت، كسينوس 90 درجه همبسـتخى آنهـا صفر و اكر كسينوس 011ا درجه همبستخى منفى است. بين تاريخ

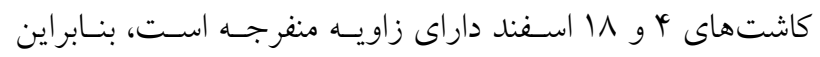

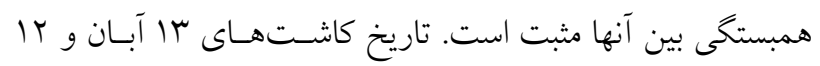
آذر نيز زاويهاى نزديك به صفر دارند. اين تاريخ كاشتها نيـز بـاــا هم همبسـتخى مثبـت دارنـد. تـاريخ كاشـتهــايى كـه بـين آنهـا همبستكى مثبت دارند واكنش هاى يكسانى با هم در عملكرد دانـه
و يايدارى بيشترى در مركز دواير متحدالمركز) رسم شده است. تاريخ كاشتى كه به اين تاريخ كاشت ايــدال نزديـكتــر باشـد،

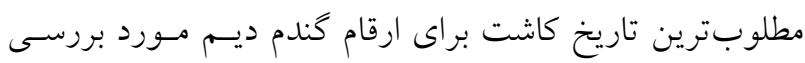
است. بنابراين تـاريخ كاشـت كاشت 9Y/9/TV نامناسبترين تاريخ كاشتها شناسايى شدند. كسينوس زاويه بين بردارها نشاندهنده همبستخى بـين تـاريخ كاشت هاى مختلف است (شكل ه). در كسينوس زواياى منفرجـه 
رهنما (9)، احمدى و همكاران ( (1)، جعفرنز اد (1) مطابقت دارد.

در مجموع نتايج نشان داد كه GGE باىيلات روشى كارا بـراى

تعيين بهترين رقم و بهترين تاريخ كاشت از بـين يـنج رقـم و 9

تاريخ كاشت بـراى يـك منطقــه اسـت و اطلاعـات مفيـدى در

خصوص زنوتيڤٍ ها و محيطهاى تحت بررسى در اختيـار قـرار

مىدهد. از طريق ايـن روش مشـخص شـــ رقـم كوهدشـت و و

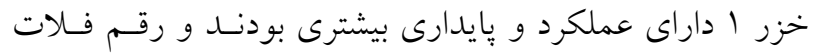

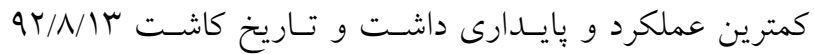

بالاترين عملكرد را داشـت و يايسـارى متوسـطى دارد و تـاريخ

كاشت 9r/N/T/ بهترين عملكرد و بايدارترين تاريخ كاشت بود

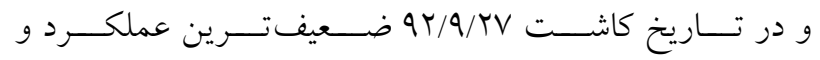

نايايدارترين تاريخ كاشـت در ايسن تحقيـق بـود. از نتـايج ايـن

تحقيق در صورتى كه در آزمايشات مشابه در مكانها و سالهاى

بيشتر نيز تأييد شوند، مىتوان براى توصيه رقم و تاريخ مناسـب

كشت در منطفه گنبد كاووس استفاده نمود.

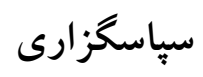

بدينوسيله از جناب آقـاى دكتـر احمدرضـا دادرس بـه جهـت

كمك در تجريه دادهها با استفاده از نرمافزار GGE Biplot كمال تشكر و قدردانى را داريم.

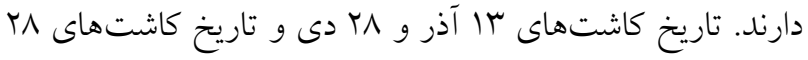

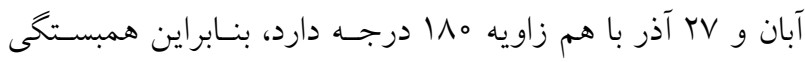
منفى در بين اين تاريخ كاشتها وجود دارد، در نتيجسه بسين ايسن تاريخ كاشتها اختلاف معنى دارى از نظر عملكــرد دانـه مشـاهده شد. ويزگ گهى ديخر در باىيلات، همبستكى بين ميحط و طـول بردار است كه تقريبى از انحراف معيار درون هر محيط بوده و نيز شاخصى تقريبى براى تمايز، در توانائى ذاتى محسيط اسـت (YD). قابليت تمايز يكى از ويزگى هاى مهم هر محيط بوده، بهطورى كـهـ محيطهاى فاقد قابليت تمايز نمىتواند اطلاعات مفيدى در مـورد

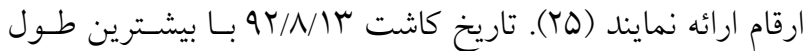
در بردار را دارد، بنابراين قابليت تمايز در عملكرد دانه در شـرايط محيطى مختلـف بيشـتر اسـت و تـاريخ كاشـتهـاى 9 و و

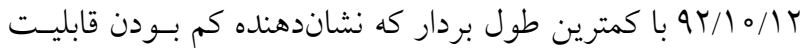
تمايز آنها است. تتيجه كيرى نتايج اين تحقيق نشان مىدهد مراحل رويشسى و زايشسى ارقـام كُندم و هم:جنين اجزاى عملكرد آنها به شـكل هـاى متفـاوت در تاريخ هاى مختلف كاشت تحت تأثير قرار مى گيــد (جــدول \&). بنابراين با تأخير در تـاريخ كاشـت موجسب كـاهش عملكـــد و اجزاى عملكرد مىشود. نتايج اين تحقيـق بـا نتـايج بخشــنده و

منابع مورد استفاده

1. Ahmadi, M., B. Kamkar, A. Soltani and E. Zeinali. 2008. Determination of the most important yield component of wheat in different sowing dates. Journal of Agricultural Science and Natural Resources 15(3): 52-64. (In Farsi).

2. Ahmadi, M., B. Kamkar, A. Soltani, E. Zeynali and R. Arabameri. 2010. The effect of planting date on duration of phonological phases in wheat cultivars and its relation with grain yield. Journal of Plant Production 17(2): 109-122. (In Farsi).

3. Akramghaderi, F., N. Latifi, J. Rezaei and A. Soltani. 2003. Effects of planting date on the phenology and morphology of three cotton cultivars in Gorgan. Iranian Journal of Agricultural Science 34(1): 221-230. (In Farsi).

4. Anandan, A., R. Eswaran, T. Sabesan and M. Prakash. 2009. AMMI analysis of yield performance in rice genotype. Advancees in Biological Research 3: 43-47.

5. Askari, A. H., A. H. Hashemi Dezfoli and D. mazaheri. 2002. The effect of planting date on limited source wheat biotypes after flowering. Seed and Plant 18(4): 394-404 (In Farsi).

6. Bakhshandeh, A. and A. Rahnama. 2005. Seed densities and planting date on tillering, yield and yield component of six promised wheat. Journal of Agricultural Science and Natural Resources 12(3): 147-254. (In Farsi).

7. Gabriel, K. R. 1971. The biplot graphic display of matrices with application to principal component analysis. Biometrika 58: 453-467. 
8. Jafarnezhad, A. 2009. Determination of optimum sowing date for bread wheat (Triticum aestivum L.) cultivars with different flowering habits in Neishabour. Seed and Plant Production Journal 2-25(2): 117-135. (In Farsi).

9. Jandong, E. A., M. I. Uguru and B. C. Oyiga. 2011. Determination of yield stability of soybean genotypes across diverse soil pH levels. Journal of Applied Biosciences 43: 2924 - 2941.

10. Kalatearabi, M., F. Shikh, H. Soghi and J. Hivechi. 2011. Effects of sowing date on grain yield and its components of two bread wheat (Triticumaestivum L) cultivars in Gorgan in Iran. Seed and Plant Production Journal 27(3): 285296. (In Farsi).

11. Kaya, Y., M. Akcura and S. Taner. 2006. GGE-biplot analysis of multienvironment yield trials in bread wheat. Turkish Journal of Agriculture and Forestry 30: 325-337.

12. Kempton, R. A. 1984. The use of biplots in interpreting variety by environment interactions. The Journal of Agricultural Science 103: 123-135.

13. Khajepour, M. R. 1999. Principle of Cultivation. Jahad Press. Isfahan.

14. Letta, T., M. G. D'Egidio and M. Abinasa. 2008. Analysis of multi-environment yield trials in durum wheat based on GGE-biplot electronic resource. Journal of Food, Agriculture and Environment 6(2): 217-221.

15. Mehrpoyan, M., G. Timas and G. R. Aminzadeh. 2010. The effect of planting date and seed density on morphological characteristics and two bread wheat cultivars yield in zone Moghan. Iranian Journal of Agricultural Science 3(9): 37- 49 (In Farsi).

16. Meseka, S. K., A. Menkir and A. E. S. Ibrahim. 2008. Yield potential and yield stability of maize hybrids selected for drought tolerance. Journal of Applied Biosciences 3: 82-90.

17. Mohammadi, R., A. Amri and Y. Ansari. 2009. Biplot Analysis of rain-fed barley multi-environment trials in Iran. Agronomy Journal 101: 789-796. (In Farsi).

18. Mohammadi, R., R. Haghparast, A. Amri and S. Ceccarelli. 2010. Yield stability of rain fed durum wheat and GGE biplot analysis of multi-environment trials. Crop and Pasture Science 61: 92-101.

19. Momtazi, F. and Y. Emam. 2006. Effect of sowing date and seeding rate on yield and yield component in winter wheat cv. Shiraz. Iranian Journal of Agricultural Sciences 37: 1-11. (In Farsi).

20. Pourdad, S. S. and M. J. Moghaddam. 2013. Study on genotype $\times$ environment interaction through GGE biplot in spring safflower (Carthamus tinctorius L.) . Journal of Crop Production and Processing 2(6): 99-107. (In Farsi).

21. Rezaei, F., M. Ghodsi and K. Klarestaghi. 2011. The study of planting date effects and plant density on yield, growth rate and agronomic traits of two triticale genotypes. Iranian Journal of Field Crops Research 3(9): $397-405$. (In Farsi).

22. Sabouri, H., H. A. Falahi, Z. Khalilno, A. R. Dadras and A. Sabouri. 2013. Study the effect of planting date on specifications agricultural of two barley cultivars. Iranian Journal of New Sustainable Agriculture 9(2): 27-34. (In Farsi).

23. Samonte, P. B., L. T. Wilson, A. M. McClung and J. C. Medley. 2005. Targeting cultivars onto rice growing environments using AMMI and SREG GGE biplot analysis. Crop Science 45: 2414-2424.

24. Yan, W. and I. Rajcan. 2002. Biplot analysis of sites and trait relations of soybean in Ontario. Crop Science 42: 1120.

25. Yan, W. and M. S. Kang. 2003. GGE biplot analysis: A graphical tool for breeders, geneticists and agronomists. CRC Press, Boca Raton, FL.

26. Yan, W. and N. A. Tinker. 2006. Biplot analysis of multi-environment trial data: Principles and applications. Canadian Journal of Plant Science 86: 623-645.

27. Yan, W., L. A. Hunt, Q. Sheng and Z. Szlavnics. 2000. Cultivar evaluation and mega-environment investigation based on the GGE biplot. Crop Science 40: 597-605.

28. Zobel, R. W., M. J. Wright and H. G. Gauch. 1988. Statistical analysis of a yield trial, Agronomy Journal 80: 388393 


\title{
Determination of Best Varieties and Planting Date for Wheat Varieties (Triticom aestivum L.) in Gonbad Kavous Using GGE Biplot Method
}

\author{
G. M. Bahalkeh¹, A. Biabani ${ }^{2}$, H. Sabouri ${ }^{*}$ and H. A. Fallahi ${ }^{3}$
}

(Received: April 22-2016; Accepted: December 2-2017)

\begin{abstract}
In order to study the effect of planting date on five cultivars of wheat (Khazar1, Falat, Zagros, Kohdasht, Karim) an experiment was conducted as a split-plot randomized complete block in Research Farm of Gonbad Kavous University, Gonbad Kavous, in northern Iran at 2013-2014. Main plots contained nine planting dates (November $4^{\text {th }}$, November $19^{\text {th }}$, December $3^{\text {rd }}$, December $18^{\text {th }}$, January $2^{\text {nd }}$, January $18^{\text {th }}$, February $8^{\text {th }}$, February $23^{\text {rd }}$ and March $9^{\text {th }}$ ) and sub plots were the cultivars. According to the Biplot, cultivar Kohdasht had the highest seed yield and medium stability and Khazar1 had the highest stability and medium grain yield. Falat produced the lowest seed yield and Karim produced the most. Planting dates of November $4^{\text {th }}$ and $19^{\text {th }}$ had the highest seed yield and stability, respectively. Kuhdasht and Khazar were the nearest to an ideal genotype and planting date of November $19^{\text {th }}$ was nearest to an ideal planting date. The cultivar Falat and planting date of December $18^{\text {th }}$ were identified as the unsuitable cultivar and planting date. All results taken together, lead us to the conclusion that seeding cultivar Kohdasht at either November $4^{\text {th }}$ or $19^{\text {th }}$ may lead to the highest and most stable seed yield, though further studies in upcoming years are recommended.
\end{abstract}

Keywords: Ideal genotype, Khohdasht cultuvar, Stability, Yeild, Yield component

1. MSc. Student, Ecological Agriculture Sciences, College of Agriculture and Natural Resources, Gonbad Kavous University, Gonbad Kavous, Iran.

2. Associate Professors, Department of Plant Production, College of Agriculture and Natural Resources, Gonbad Kavous University, Gonbad Kavous, Iran.

3. Assistant Professor of Horticulture Crops Research Department, Mazandaran Agricultural and Natural Resources Research and Education Center, AREEO, Sari, Iran.

*. Corresponding Author, Email: hos.sabori@gmail.com 